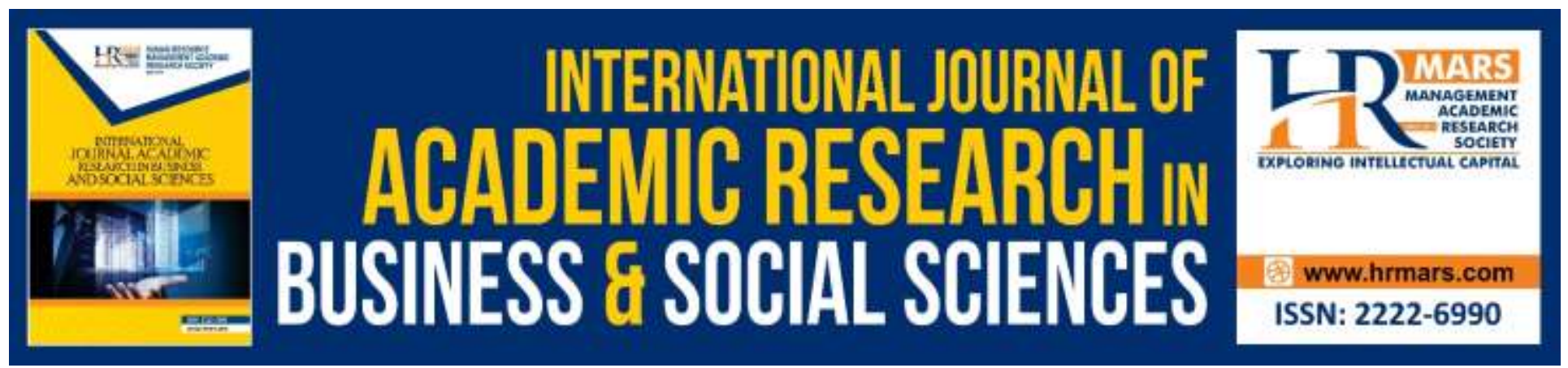

\title{
Determinants of Public University Student's Impulse Purchase Behaviour in Malaysia
}

Munirah Mohamed, Nazwa Nurshahida Mohamed Nazaruddin, Noorain Mohd Nordin, Nurul Azrin Ariffin, Nurhaslinda Hashim

To Link this Article: http://dx.doi.org/10.6007/IJARBSS/v10-i4/7149

DOI:10.6007/IJARBSS/v10-i4/7149

Received: 17 February 2020, Revised: 21 March 2020, Accepted: 26 March 2020

Published Online: 19 April 2020

In-Text Citation: (Mohamed et al., 2020)

To Cite this Article: Mohamed, M., Nazaruddin, N. N. M., Nordin, N. M., Ariffin, N. A., \& Hashim, N. (2020). Determinants of Public University Student's Impulse Purchase Behaviour in Malaysia. International Journal of Academic Research in Business and Social Sciences, 10(4), 483-494.

\section{Copyright: (C) 2020 The Author(s)}

Published by Human Resource Management Academic Research Society (www.hrmars.com)

This article is published under the Creative Commons Attribution (CC BY 4.0) license. Anyone may reproduce, distribute, translate and create derivative works of this article (for both commercial and non-commercial purposes), subject to full attribution to the original publication and authors. The full terms of this license may be seen

at: http://creativecommons.org/licences/by/4.0/legalcode

Vol. 10, No. 4, 2020, Pg. 483 - 494

http://hrmars.com/index.php/pages/detail/IJARBSS

JOURNAL HOMEPAGE

Full Terms \& Conditions of access and use can be found at http://hrmars.com/index.php/pages/detail/publication-ethics 


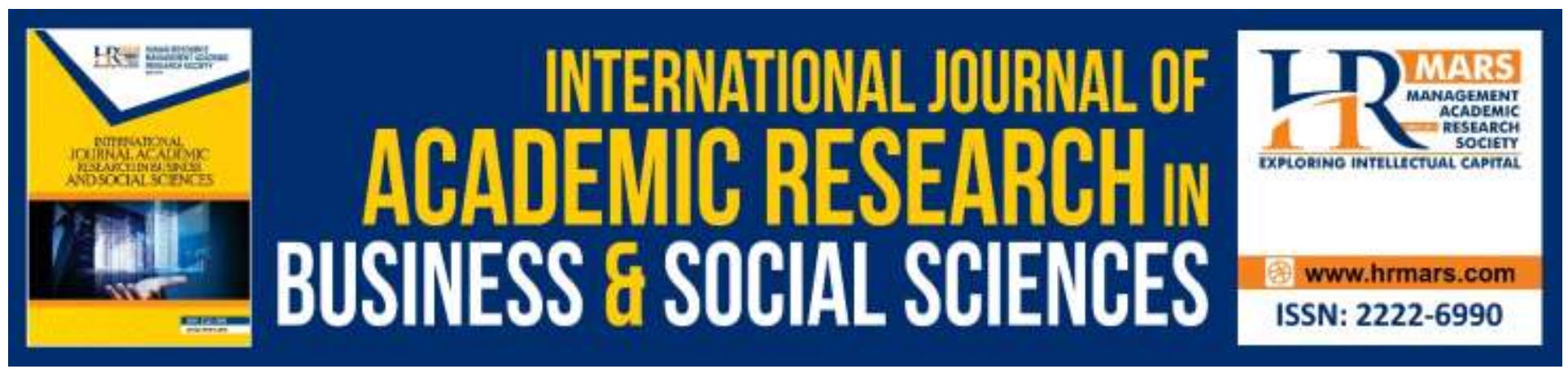

\title{
Determinants of Public University Student's Impulse Purchase Behaviour in Malaysia
}

\author{
Munirah Mohamed, Nazwa Nurshahida Mohamed Nazaruddin, \\ Noorain Mohd Nordin, Nurul Azrin Ariffin, Nurhaslinda Hashim \\ Faculty of Business and Management, Universiti Teknologi MARA Cawangan Melaka \\ Email: munirah257@uitm.edu.my
}

\begin{abstract}
The impulse purchase behaviour among the consumer could be great opportunities for every seller or retailers to increase their sales and directly the profits as well which makes this kind of behaviour are pretty much welcomed in every stores. However, it has been related to the increase of debt, wasting money, illiteracy on personal financing and lack of sense on differentiate needs and wants of a consumer. Hence, the aim of this study is to examine the factors influencing public university student's impulse purchase behaviour specifically among Faculty Business and Management students in UiTM Cawangan Melaka Kampus Bandaraya Melaka. The dependent variable in this study was impulse purchase behaviour while the independent variables were made up of four variables which are prominent product display, broad assortment, price promotion and customer characteristic. A total of 308 respondents has completed the survey questionnaire and the Statistical Package for Social Sciences Software (SPSS) was used to analyse all the data obtained. A multiple regression analysis was used to test the relationship among the variables. The result indicates that broad assortment, price promotion and customer characteristic have significant relationship with impulse purchase behaviour. The most significant predictor variable of consumer's impulse purchase behaviour is customer characteristic which found that customer characteristic that are tend to impulse purchases will be have more tendency to be influenced for impulse purchase behaviour. The findings of this research can be very helpful and useful to producers, retailers, companies and marketers as well to improve and increase the potential of more profits and presenting a better image or perception towards the consumers. This research could be helping the consumer on understanding and realizing the tricks that were done by companies or marketers to make them pay and spend more.
\end{abstract}

Keywords: Impulse Purchase Behaviour, Prominent Product Display, Broad Assortment, Price Promotion, Customer Characteristics. 
INTERNATIONAL JOURNAL OF ACADEMIC RESEARCH IN BUSINESS AND SOCIAL SCIENCES

Vol. 10, No. 4, April, 2020, E-ISSN: 2222-6990 @ 2020 HRMARS

\section{Introduction}

Impulse purchase usually known as the unplanned purchase by the consumer or buyer as they did not think that much before making a decision on purchasing certain goods (Lau, Cham, \& Ng, 2018). The impulse purchase behaviour among the consumer could be great opportunities for every seller or retailers to increase their sales and directly the profits as well which makes this kind of behaviour are pretty much welcomed in every stores (Khan, Hui, et. al, 2016). The consumer's impulse purchase behaviour is one of the proofs of the marketing strategy success of certain brands or retailers or sellers as it intensifies the consumer behaviour on purchasing their goods or consumer opening their wallet to buy since there were several tools of marketing strategy that was used to make sure this kind of behaviour are arouse among the consumer (Lama , 2018).

This phenomenon has been known throughout the world and a great impact to the nation's economy has led to many studies done in several countries such as Singapore, United States of America, Indonesia, France, South Africa, Iran and China as well (Lau, Cham, et.al, 2018). In Singapore, 4 in 5 Singaporeans are the online impulse buyers as they using the mobile devices as the companion to the online shopping (Charlton Media Group, 2016). In United States of America(USA), impulse purchase behaviours is very common among the millenials where more than $80 \%$ of them has made an impulse purchase. The USA millenials stated that not all of them feel great about the impulse purchases they have made where they have felt more regrets and the tendency of dissatisfactions with their impulse purchase behaviour (eMarketer Incorporation, 2015). The impulse purchase behaviour phenomenon also can be seen in Malaysia as said by Malaysia Retail Chain Association (MRCA) president Datuk Seri Garry Chua, Malaysia will have at least 700 shopping malls in 2019 as the high value retail goods received $30 \%$ increase in business such as mobile phones, gadgets, fashion and luxury items compared to the basic necessities (Kaur , 2018).

Unfortunately, there were several problems and issues that has been garnered at the sight of consumer where the impulse purchase behaviour has been related to the increase of debt, wasting money, illiteracy on personal financing and lack of sense on differentiate needs and wants (Nur, 2019).This behaviour that happen frequently has led to a several problem and issues among the consumer which are spending more than what they capable, increase of debt and lack of sense on differentiate needs and wants. The next problem is the lack of sense on differentiating needs and wants where based on the SAYS news, Malaysian students don't have enough money to feed themselves due to the impulse purchase behaviours as their one of bad spending habits (Ruxyn, 2016). This news can be supported by a saying from Dr. Tuan Zainun Tuan Mat, Universiti Teknologi Mara (UiTM) Faculty of Accountancy Associate Professor who stated that the current generation of student are lacking on the ability to differentiate between needs and wants where most of the students have tendency to keep up with the trend just to be at the same level of status with their friends which makes them over spend and having no money are the common problem happen among the university students (Sani, 2019).

Several factors of consumer impulse purchase behaviours were identified such as the credit card usage, internet access to purchase online, friends and family influences, sales promotion, money availability, personality traits and store environment (Bhasin, 2019). Therefore, additional research is necessary to identify the factors influence the impulse purchase behaviour among university students as the consumer. This research has intended to help the students as the consumer on the exposure and comprehension about this issues where it could make them being in a problematic position when 
INTERNATIONAL JOURNAL OF ACADEMIC RESEARCH IN BUSINESS AND SOCIAL SCIENCES

Vol. 10, No. 4, April, 2020, E-ISSN: 2222-6990 @ 2020 HRMARS

it could be avoided by increasing their own awareness. Thus, researcher intend to investigate the factors influencing consumer's impulse purchase behaviour among UiTM students.

\section{Literature Review}

\section{Impulse Purchase Behaviour}

According to Karbasivar and Yarahmadi (2011), impulse purchase behaviour were divided into four different types based on Sterns separation which are planned impulse purchase, reminded impulse purchase, fashion-oriented impulse purchase and pure impulse purchase. Stern (1962) study mentioned that a pure impulse purchase is the emotional appeal that highly influence spontaneous purchased and the cognitive involvement are less. Statement by Stern (1962), a suggested impulse purchase could also happen when the consumer happened to see the products for the first time and it triggers the desire of consumer to buy even the consumer has no prior knowledge regarding the products.

Based on previous studies, the impulsive purchase was seen as a simple formula, "Impulse Purchasing = Unplanned Purchasing + Exposure to a Stimulus" (Piron, 1991). Previous research by Tendai and Crispen (2009) resulted on the pricing strategy and the coupon are more likely influence the impulsive buying than the store environment effects by using music and scent. The impulse purchase behaviour is known to be influenced by the inputs component which are the marketing activities of the businesses such as the pricing reductions, products size or guarantee and the distribution (Schiffman \& Kanuk, 2007). Therefore, amongst all antecedents of impulse purchase behaviour, there are four (4) dominant factors that researched in this study which is prominent product display, broad assortment, price promotion and customer characteristic.

\section{Prominent Product Display}

Prominent product display is part of the concerned on how the products are communicating to the consumer which through the product arrangement as the criteria on presenting the product most appealing way to the consumer and making sure that a positive image of the product could be interpret by the consumer as it was intended by the store (Kerfoot, Davies , \& Ward , 2003). Through the window display done by the store, specific first impressions could be created and a minimal attention could be received by the store as the physical attractiveness could be maximize through the product display (Karbasivar \& Yarahmadi, 2011). Product display were applied as an instant information transmission through the visual stimuli as an example the mannequin used as window display give a specific information to consumer where they could visualize how the products would look on them (Zainal Abidin \& Abdul Aziz, 2010).

The prominent product display that are known to be part of marketing strategy has a strong relation in consumer impulse purchase behaviour if a strong strategy were used which is known to be a success in influencing the consumer (Vishnu \& Raheem , 2013). As an encouragement to consumer impulse purchase behaviour, the product displays would be a huge support in appealing to the consumer easily (Kacen, Hess , \& Walker , 2012). Consumer impulse purchase behaviour could also be influence due to the product placement that are easy to be seen and grab instantly especially near the checkout counter where most of consumer will spend time on waiting in the queue to pay (Cohen , Collins, et.al, 2014). One of the key in affecting consumer behaviour in impulse purchases is through the visual merchandising elements which was considered to be the colours of products, 
INTERNATIONAL JOURNAL OF ACADEMIC RESEARCH IN BUSINESS AND SOCIAL SCIENCES Vol. 10, No. 4, April, 2020, E-ISSN: 2222-6990 @ 2020 HRMARS

lighting on the products, location of the products, store layout and store equipment (Kerfoot, Davies, \& Ward, 2003).

Regardless, the attractive prominent product display served as positive vibe towards consumer in evaluating the quality of product and perception of the products and store which would increase consumer participation in the store naturally and lead to a favourable buying behaviour (Law, Wong, \& Yip, 2012). Therefore, this study hypothesizes there is a positive and significant relationship between prominent product display and impulse purchase behaviour; Hypothesis $1\left(\mathrm{H}_{1}\right)$.

\section{Broad Assortment}

Broad product assortment is considered to be an important strategy for many retailers as it aimed to give a positive reaction from consumer to make sure it can be easily remembered by them (Lau, Cham, \& Ng, 2018). According to Broniarczyk and Hoyer (2010), broad product assortment strategy has gone to drastic changes from the early 1990s where the unparalleled large assortments were done until this day, the large assortment was focusing on streamlined and efficient assortment. This broad product assortment strategy has undergone drastic changes which shows the positivity and the need of this strategy to be done as it increased the impulse purchase behaviour among consumer when they come across a broad range of product assortment or categories (Hulten \& Vanyushyn, 2011).

The sudden urge of impulse purchase behaviour also could be exist due to the broad product assortment strategy as there may be hedonic motives that is known to be pleasure or excitement feeling of the consumer during shopping and the hedonic motives can be triggered as simple as remembering that spaghetti is missing at home and so the consumer directly buy it without intention at the first place (Heilman, Nakamoto, \& Rao, 2002). Broad product assortment can easily attract the consumer to buy the products spontaneously right before they make payment at the counter check (Park, Kim, Funches, \& Foxx, 2012). This attraction could be easily done when the products range number were increase at the moment consumer have to be waiting in queue to pay and positive impressions could be made as they unintentionally look through the products at the counter check (Hulten \& Vanyushyn, 2011). Therefore, this study hypothesizes there is a positive and significant relationship between broad assortment and impulse purchase behaviour; Hypothesis $2\left(\mathrm{H}_{2}\right)$.

\section{Price Promotion}

Price promotion is part of advantages and benefits for consumer in terms of reducing their expenses and saving more, it also may help them on decision making during purchasing and part of encouragement to the consumer in trying new products that they have never tried before (Chandon , Wansink, \& Laurent, 2000). Observations made through the price promotion with an increase of quantity products at the same price or low price for specific quantity, could actually be useful to attract new consumer and stimulate them to get the product during off price (Ismail \& Siddiqui, 2019). When price promotion was done, it could also assist in boosting the consumer numbers within the stores as it easily attracts them (Sawyer \& Dickson, 1984).

Price promotion strategy were given high interest among the marketing scholars as it given higher advantages on attracting the consumer (Chandon, Wansink, \& Laurent, 2000). Especially for the consumer impulse purchase behaviour on convenience goods and groceries where the price is part of the important factor that will be considered by the consumer (Janakiraman, Meyer, \& 
INTERNATIONAL JOURNAL OF ACADEMIC RESEARCH IN BUSINESS AND SOCIAL SCIENCES Vol. 10, No. 4, April, 2020, E-ISSN: 2222-6990 @ 2020 HRMARS

Morales, 2006). According to Tendai and Crispen (2009), higher opportunities could be create for impulse purchase behaviour among consumer when the lower price tag was created. The products that are on sale would have the higher chances to impulsively bought compared to the products that are not on sales (Kacen, Hess, \& Walker, 2012). Therefore, this study hypothesizes there is a positive and significant relationship between price promotion and impulse purchase behaviour; Hypothesis 3 $\left(\mathrm{H}_{3}\right)$.

\section{Customer Characteristic}

Customer characteristic is part of the personal traits of the consumer in terms of the knowledge and excitement feelings towards certain product's buying decisions that they have made (Lau, Cham, \& Ng, 2018). According to Harmancioglu, et.al (2009), majority of the consumer will be using the in-store environment to remember but they also will be encouraged by their own personal characteristics that depends on their own knowledge and impressions they have regarding the products even before they made any purchases. The consumer personality also known to be the internal factors where the impulse purchase behaviour were done due to their own excitement feelings on the urge to buy something, to keep-up with the current trends, or their own thoughts that they would probably need the goods later but it end-up wasted (Hussain \& Siddiqui, 2019).

Before this, the impulse purchase behaviour are constantly relate to the external factors but the behaviour of consumers during purchasing goods cannot be denied as it came from their own characters which the consumer urge or tendency on purchasing goods that were not in their planned list or shopping list are part of the personal characteristics affecting the impulse purchase behaviour (Rook \& Fisher, 1995). Therefore, this study hypothesizes there is a positive and significant relationship between customer characteristic and impulse purchase behaviour; Hypothesis $4\left(\mathrm{H}_{4}\right)$.

\section{Research Methodology}

The purpose of this research is to investigate the relationship between prominent product display, broad assortment, price promotion, and customer characteristic and impulse purchase behaviour among Faculty of Business and Management (FBM) students in UiTM Cawangan Melaka, Kampus Bandaraya Melaka from the range age 19 years old to 30 years old. The reason in choosing FBM students is because of the knowledge specifically related to those program in the faculty. The questionnaires consist of six sections. Section $A$ includes the demographic detail of respondents. Section $B, C, D$, and $E$ are related to the independent variables of the study; while section $F$ is related to the dependent variable. A total of 317 questionnaires distributed to students and 308 valid questionnaires returned. Hence, the response rate for this study is $97.16 \%$.

The measurement items in this study were adopted from previous and established instruments. Specifically, all variables were adopted from Lau, Cham, \& Ng (2018) with 24 items. Besides that there 6 items on the demographic profile that is developed by the researchers. The internal consistency reliability analysis of all measurement items was assessed through Cronbach alpha $(\alpha)$ and revealed that all the scales adopted in this study were accepted with alpha's value between $0.728<\alpha<0.858$. Multivariate statistical analysis using Statistical Package for the Social Science (SPSS) software was carried out to analyse the data collected. The findings in this study reported through analyses of descriptive statistics, frequency, and multiple regression analysis. 
INTERNATIONAL JOURNAL OF ACADEMIC RESEARCH IN BUSINESS AND SOCIAL SCIENCES

Vol. 10, No. 4, April, 2020, E-ISSN: 2222-6990 @ 2020 HRMARS

\section{Findings}

\section{Respondents' Background}

Majority of the respondents are female contributed the most with a total of 234 respondents (76\%) compared to male with only a total of 74 respondents (24\%). In addition, respondents with age within 19 to 22 years old had dominated the study with a total of 196 respondents (63.6\%). Also, students that studies in program of Bachelor of Business Administration (Hons) Finance (BA242) are the majority of the respondent with a total of 99 respondents (32.1\%). Next, the monthly expenses amount by the respondents were agreed to be RM100 to RM300 with a total of 112 respondents (36.4\%). Even though, some of respondents were married but 300 respondents $(97.4 \%)$ are mostly single which takes the lead with by far amount. Lastly, the majority of the respondents were agreed with the products of food and beverages as the products purchased by them with the huge lead with 124 respondents $(40.3 \%)$.

\section{Mean and Regressions Analyses}

The descriptive statistics analysis findings; mean and standard deviation shown based on table 1. The highest mean value is price promotion with $m=4.0855 ; S D=0.75254$. Then followed with customer characteristic $(\mathrm{m}=4.0701 ; \mathrm{SD}=0.56223)$, prominent product display $(\mathrm{m}=3.9058$; $\mathrm{SD}=0.72253)$, broad assortment $(\mathrm{m}=3.7944 ; \mathrm{SD}=0.74287)$ and impulse purchase behaviour $(\mathrm{m}=3.6778 ; \mathrm{SD}=0.85720)$.

Table 1: Mean and Standard Deviation

\begin{tabular}{lcc}
\hline & $\mathbf{m}$ & SD \\
\hline Impulse Purchase Behaviour & 3.6778 & 0.85720 \\
Prominent Product Display & 3.9058 & 0.72253 \\
Broad Assortment & 3.7944 & 0.74287 \\
Price Promotion & 4.0855 & 0.75254 \\
Customer Characteristic & 4.0701 & 0.56223 \\
\hline
\end{tabular}

The hypotheses of this study were investigated through multiple linear regressions as reported in Table 2 . There were 4 hypotheses that have been tested. The table findings indicated that the model was statistically significant, as the F-value obtained was 32.643 with significant value at 0.00 . Hence, the model is statistically fit and significant. The R-squared value attained was 0.301 . This implies that $30.1 \%$ of variance in dependent variable, impulse purchase behaviour was explained by the variation of all independent variables namely, prominent product display, broad assortment, price promotion and customer characteristic. The remaining variance of $69.9 \%$ that explain the dependent variable can be explained by other independent variables outside the study. The results of multiple linear regressions revealed that only 3 independent variables; broad assortment $(\beta=0.206)$; price promotion ( $\beta=0.184)$; and customer characteristic $(\beta=0.312)$ shown a positive and significant relationship with dependent variable. Meanwhile, prominent product display $(\beta=-0.028)$ had no significant relationship with impulse purchase behaviour. The most influence factor was customer characteristic with the highest beta value $(\beta=0.312)$. Therefore, the results of the hypotheses proved that only $\mathrm{H}_{2}, \mathrm{H}_{3}$, and $\mathrm{H}_{4}$ were supported, while $\mathrm{H}_{1}$ was not supported. 
INTERNATIONAL JOURNAL OF ACADEMIC RESEARCH IN BUSINESS AND SOCIAL SCIENCES Vol. 10, No. 4, April, 2020, E-ISSN: 2222-6990 @ 2020 HRMARS

Table 2: Multiple Regression Analysis

\begin{tabular}{lccc}
\hline & $\begin{array}{c}\text { Standard } \\
\text { Coefficients (Beta) }\end{array}$ & $\mathbf{t}$ & Sig. \\
\hline Prominent Product & -.028 & -.482 & .630 \\
Display & & & \\
Broad Assortment & .206 & 3.369 & .001 \\
Price Promotion & .184 & 3.374 & .001 \\
Customer Characteristic & .312 & 5.130 & .000 \\
\hline F value = 32.643 & & \\
\hline Significant = 0.000 & & \\
\hline R-Square $=.301$ & & \\
\hline Note: $*$ p<0.05, ANOVA, Sig. at 0.00 & & \\
\hline a. Predictors: (Constant), Prominent Product Display, & Broad Assortment, Price & Promotion, \\
Customer Characteristic & & \\
\hline b. Dependent Variable: Impulse Purchase Behaviour & \\
\hline
\end{tabular}

\section{Conclusion and Discussion}

The purpose of this research is to identify factors that influence student's impulse purchase behaviour in Malaysia. Based on previous researchers, there were several predictors influenced to impulse purchase behaviour, including prominent product display, broad assortment, price promotion and customer characteristic. Therefore, there are four hypotheses for this research that requires validation.

Based on the multiple regression analysis findings, it reveals hypothesis $1\left(\mathrm{H}_{1}\right)$, there had no significant relationship between prominent product display and impulse purchase behaviour. The result of this study is not significant as compared to previous research because the possibility of the respondents lacked of understanding regarding the items and there is also a possibility where the consumer's thought that impulse purchase behaviour is a sudden urges and unplanned which the product display was not important for their sudden action. Gudonaviciene and Alijosiene (2015) stated that the product chosen for the research also is very important as their previous research reference stated the product display is important as the product purchase was specialized in clothing and footwear but if the research were done for food products, the product display may have a different major impacts as the behaviour on buying food and clothing is different which the number of respondents were choosing food, drinks, candy and chocolate were higher compared to clothing and shoes, cigarettes and others. This proved that prominent product display would have no significance towards impulse purchase behaviour among consumers since the outcome of study has supported the statement.

Next, hypothesis $2\left(\mathrm{H}_{2}\right)$ was accepted and revealed that there is a positive and significant relationship between broad assortment and impulse purchase behaviour. The outcome of this study is aligned with previous research as mentioned in Chapter 2. Lau, Cham and Ng (2018), where the previous studies found a positive effect towards consumer's impulse purchase behaviour through a broad product assessment. Through this outcomes, it shows that varieties of product available could actually be considers as a better service for the consumers when it expands as it may increase the possibility to fulfil the consumer's needs and wants. Moreover, the finding was also consistent with 
the evidence from previous research studies by Hultén and Vanyushyn (2011). This finding actually give a lot of exposure towards the marketers where they should be sensitive to consumer needs and wants and definitely keep trying, attending to it in an efficient manner. In this research, most of the respondents agreed that the varieties of product existences actually helping them in reminding what they really need to buy. As the consumer, respondents agreed that they tend to buy some of the products that were being assorted throughout the store and the broad assortment of multiple products actually helps them to buy several items in a single visit.

Hypothesis $3\left(\mathrm{H}_{3}\right)$ also was accepted and shown significant relationship between price promotion and impulse purchase behaviour. In this research, the respondents agreed that if there were any interesting promotional offer that they see on the in-store signs, they will buy the products and a buy-one-get-one-free also led them to buy the products. Besides that, a coupon of the store has also increase the consumer tendency to buy the products which they did not plan to buy before. It is aligned with previous research by Lau, Cham and Ng (2018), where the previous studies found a great positive effect towards consumer's impulse purchase behaviour through price promotion. Through this outcomes, it shows that price promotion is an effective strategy that could actually be considers in attracting the consumer to approach the products and directly purchase the products even without any intention at the first place. Moreover, Rasheed, Baig and Yaqub (2017) studies stated that price promotion could give a great positive images of the products or brands as the price were used as a persuasion of the seller to consumer to buy and try the products. The price promotion on certain products also could motivates the consumer on buying the products even though it was not an essential needs to them (Tendai \& Crispen, 2009).

Finally, hypothesis $4\left(\mathrm{H}_{4}\right)$ shown that there was a significant relationship between customer characteristic and impulse purchase behaviour. In this research, most of the respondent agreed that when they found some products that were really nice, it will make them feel good and cheers them up. Besides that, the purchasing was mostly done when the respondents are in a care free mood. Through this research also, it is proved that a sense of excitement was felt by the respondents as the consumer whenever they make an impulse purchase. Lau, Cham and Ng (2018), where the previous studies found a positive effect towards consumer's impulse purchase behaviour through consumer's personal characteristic. Through this outcomes, it shows that customer characteristic would be possible as they have a certain understanding or images on certain product that were formed through previous experiences on using it and specific knowledge that lead to the impulsiveness of consumer to buy the products and it will be irresistible for them not to buy the products.

\section{Recommendations}

From the findings of this research, there are few recommendations for future researcher and practitioner's improvement. Future researcher should consider the influence of various culture in addressing the consumer's impulse purchase behaviour (Lau, Cham, \& Yat Ng, 2018). Other variables that could be done stated by Bhasin (2019) is the credit card usage, internet access to purchase online, friends and family influences, sales promotion, money availability and store environment. As through the research findings there are $69.9 \%$ possibility of other variables influencing the consumer's impulse purchase behaviour.

Customer characteristic had a significant relationship with consumer's impulse purchase behaviour. This means that when consumer personal characteristic was known to has habit of 
impulse purchasing or they possibly have the knowledge and experience on using and having the products which means that the individuals will have a better lead on impulse purchase behaviour. Thus, another marketing strategy targeting this type of consumer could be done to triggers the consumer impulse purchase behaviour. Through Lau, Cham and Ng (2018) research findings, they stated that the impulse purchase behaviour will be more likely be influence when they have a certain impression on the products that were gained through experience on using it which most of the marketers were recommended on understanding the consumer's psychological responses on certain strategy that will be affecting or triggering the consumer impulse purchase behaviour the best. As for the consumer, the best way to actually notice and avoid the impulse purchase behaviour was by creating a budget of expenses which will make the consumer think about the needs and wants when spending the money (Duffy, 2019).

As broad assortment, when consumer has high exposure towards varieties products available which means that the individuals will have a better lead on impulse purchase behaviour. Thus, an extension of product assortment could be done to increase the influence of consumer impulse purchase behaviour. According to Boatwright \& Nunes (2004) research, the product assortment can be done by trimming the brand-size combinations such an example was given, an assortment of 6 products were done and offered in specific assortment which are brand $A$ in size $X$, size $Y$ and size $Z$ and the brand $B$ were also offered in the same 3 sizes which this could be done to increase the assortments of products offered in the store while reducing the product size of display.

The outcome of the research indicated that price promotion has significant relationship with consumer's impulse purchase behaviour. This means that when consumer has more attention and interest towards products sell through promotion which means that the individuals will have a better lead on impulse purchase behaviour when the price promotion happen. Thus, a price promotion improvement could be done to increase the influence of consumer impulse purchase behaviour. Ismail and Siddiqui (2019), stated that the promotion price could be improve to engage with consumer in a better way which the store should be placed the products that have price promotion on an attractive shelves and also the price promotion products should be separated and mentioned according to the categories and assortment.

\section{Acknowledgement}

The author would like to thank the co-authors that have helped in conducting and completing this research. This research was fully supported by conference funds under Universiti Teknologi MARA Cawangan Melaka, Malaysia.

\section{Corresponding Author}

Munirah Mohamed

Faculty of Business and Management

Universiti Teknologi MARA Cawangan Melaka, Malaysia

Email: munirah257@uitm.edu.my

\section{References}

Bhasin, H. (2019). What Is Impulse Buying? What Are The Factors Influencing Impulse Buying. Retrieved from Marketing 91: https://www.marketing91.com/impulse-buying/ 
INTERNATIONAL JOURNAL OF ACADEMIC RESEARCH IN BUSINESS AND SOCIAL SCIENCES Vol. 10, No. 4, April, 2020, E-ISSN: 2222-6990 @ 2020 HRMARS

Boatwright, P., \& Nunes, J. C. (2004). Reducing Assortment: An Attribute-Based Approach. Journal of Marketing, 50-63.

Broniarczyk, S. M., \& Hoyer, W. D. (2010). Retail Assortment: More $\neq$ Better. Retailing in the 21st Century, 271-284.

Chandon, P., Wansink, B., \& Laurent, G. (2000). A Benefit Congruency Framework of Sales Promotion Effectiveness. Journal of Marketing, 65-81.

Charlton Media Group. (2016). 4 in 5 Singaporeans are online impulse buyers. Singapore Business Review. Retrieved from Singapore Business Review: https://sbr.com.sg/retail/in-focus/4-in-5singaporeans-are-online-impulse-buyers

Cohen, D. A., Collins, R. L., Hunter, G., \& Dubowitz, T. (2014). Store Impulse Marketing Strategies and Body Mass Index. American Journal of Public Health, 1446-1452.

Duffy, E. (2019). Credits Card: 12 Ways to Stop Impulse Buying. Retrieved from Savings.com.au: https://www.savings.com.au/credit-cards/impulse-buying-how-to-control-your-shoppingaddiction-savings-com-au

eMarketer Incorporation. (2015). Millennials Admit to Impulse Shopping. eMarketer. Retrieved from eMarketer Web Site: https://www.emarketer.com/Article/Millennials-Admit-ImpulseShopping/1011834

Gudonaviciene, R., \& Alijosiene, S. (2015). Visual Merchandising Impact on Impulse Buying Behaviour. Procedia Social and Behavioral Sciences 213, pp. 635-640.

Harmancioglu, N., Finney, R., \& Joseph M. (2009). Impulse Purchases of New Products: An Empirical Analysis. Journal of Product and Brand Management, 27-37.

Heilman, C. M., Nakamoto, K., \& Rao, A. G. (2002). Pleasant Surprises: Consumer Response to Unexpected In-Store Coupons. Journal of Marketing Research, 241-252.

Hulten, P., \& Vanyushyn, V. (2011). Impulse Purchases of Groceries in France and Sweden. Journal of Consumer Marketing, 376-384.

Hussain, S., \& Siddiqui, D. A. (2019). The Influence of Impulsive Personality Traits and Store Environment on Impulse Buying of Consumer in Karachi. International Journal of Business Administration, 50-73.

Ismail, A., \& Siddiqui, D. A. (2019). Impact of sales promotion on consumer impulse purchases in Karachi. Pakistan: Karachi University Business School.

Janakiraman, N., Meyer, R. J., \& Morales, A. C. (2006). Spill over Effects: How Consumers Respond to Unexpected Changes in Prices and Quality. Journal of Consumer Research, 361-369.

Kacen, J. J., Hess, J. D., \& Walker, D. (2012). Spontaneous Selection: The Influence of Product and Retailing Factors on Consumer Impulse Purchases. Journal of Retailing and Consumer Services, 578-588.

Karbasivar, A., \& Yarahmadi, H. (2011). Evaluating Effective Factors on Consumer Impulse Buying Behavior. Asian Journal of Business Management Studies 2 (4), 174-181.

Kaur, S. (25 October, 2018). 700 Shopping Malls by End of Next Year? New Straits Times.

Kerfoot, S., Davies, B., \& Ward, P. (2003). Visual Merchandising and The Creation of Discernible Retail Brands. International Journal of Retail \& Distribution Management, Vol 31. (3) 143-152. Khan, N., Hui, L., Chen, T., \& Hoe, H. (2016). Impulse Buying Behaviour of Generation Y in Fashion Retail. International Journal of Business and Management, 11(1), 144. 
INTERNATIONAL JOURNAL OF ACADEMIC RESEARCH IN BUSINESS AND SOCIAL SCIENCES

Vol. 10, No. 4, April, 2020, E-ISSN: 2222-6990 @ 2020 HRMARS

Lama, K. (2018). Factors Influencing Consumer Buying Behavior toward Impulse Buying. The International Journal of Business and Management, 245-258.

Lau, T. C., Cham, T. H., \& Yat Ng, D. C. (2018). How Susceptible are Consumers in Impulse Purchasing Ready-to-Drink Products? Evidence from Malaysia. International Journal of Academic Research in Business and Social Sciences, 429-444.

Law, D., Wong, C., \& Yip, J. (2012). How Does Visual Merchandising Affect Consumer Affective Response? An Intimate Apparel Experience . European Journal of Marketing Vol. 46, 112-133.

Nur, A. (2019). Young People's Debt Woes Bode III for Economy. The Sun Daily. Retrieved from The Sun Daily: https://www.thesundaily.my/local/young-people-s-debt-woes-bode-ill-for-economyIN1395930

Park, E. J., Kim, E. Y., Funches, V. M., \& Foxx, W. (2012). Apparel Product Attributes, Web Browsing, and E-Impulse Buying on Shopping Websites. Journal of Business Research, 1583-1589.

Piron, F. (1991). "Defining Impulse Purchasing". Advances in Consumer Research, Vol.18, 509-514.

Rasheed, A., Baig, F. J., \& Yaqub, S. R. M. (2017). Factors Affecting Impulse Buying Behaviors in Shopping Malls: Evidence from Bahawalpur Region, Pakistan. Journal of Marketing and Consumer Research, 01-20.

Rook, D. W., \& Fisher, R. J. (1995). Normative Influences on Impulsive Buying Behavior. Journal in Consumer Research, 305-313.

Ruxyn, T. (2016). Malaysian Students Don't Have Enough Money to Feed Themselves. But Why Are They So Broke? Retrieved from SAYS: https://says.com/my/news/poor-malaysian-students.

Sani, R. (2019). Money woes at university. Retrieved from New Straits Times: https://www.nst.com.my/education/2019/04/475754/money-woes-university

Sawyer, A. G., \& Dickson, P. R. (1984). Psychological Perspectives on Consumer Responses to Sales Promotion. Cambridge MA: Marketing Science Institute.

Schiffman, L., \& Kanuk, L. (2007). Consumer Behaviour (9th Edition). New Jersey: Prentice Hall. Stern, H. (1962). The Significance of Impulse Buying Today. Journal of Marketing, 26 (2), 59-62.

Tendai, M., \& Crispen, C. (2009). In-Store Shopping Environment and Impulsive Buying. African Journal of Marketing Management, 102-108.

Vishnu, P., \& Raheem, A. R. (2013). Factors Influencing Impulse Buying Behavior . European Journal of Scientific Research, Vol. 100 (3): 67-79.

Zainal Abidin, N. Z., \& Abdul Aziz, A. (2010). Window Display Compositions: Its Influences on Youths in Malaysia. Asia Pacific International Conference on Environment-Behaviour Studies (pp. 355 361). Kuching, Sarawak, Malaysia: Elsevier B.V. 